\title{
Constructing Buddhism(s): Interreligious Dialogue and Religious Hybridity
}

\author{
Courtney Bender* \\ Columbia University \\ and \\ Wendy Cadge* \\ Brandeis University
}

This paper presents data from interviews with senior Catholic and Buddhist nuns living in the United States who participated in an interreligious dialogue. We focus on how Catholic nuns develop, appropriate, and adapt Buddhist forms and ideas in their daily religious practices and how Buddhist nuns respond. We describe and analyze three distinct discursive constructions of Buddhism that Catholic and Buddhist nuns draw upon, and discuss the significance of these constructions for members of both traditions as they think about their groups' futures. This material contributes to research on religious syncretism, appropriation, and the hybrid nature of religious traditions in practice

While some scholars conceive of religions as intact traditions with clear boundaries, distinct ideologies, and unique histories other scholars, primarily in sociology and religious studies, have long known that these conceptions fall apart under close scrutiny (Boyarin 2004; Butler 1990; Thal 2005). Religious traditions develop and exist, these others argue, in relation to one another. Religious conflicts and polemics reformulate and solidify boundaries between traditions. The movement of religious traditions into new contexts reshapes their borders and meanings, and contact and interaction in plural worlds often lead to religious hybridization and other kinds of incorporation (McGuire and Maduro 2005; Biernatzki 1991; Orsi 2003; Klassen 2005).

\footnotetext{
*Send correspondence to: Courtney Bender, Department of Religion, Columbia University, 80 Claremont Ave, New York, New York 10027 cb337@columbia.edu. Research support for this project was provided by Bowdoin College and the Society for the Scientific Study of Religion. Thanks to Heather Day, Joy Lee, Nicole Melas, and Tahlya Paynter for help with transcription and to Amy Koehlinger, three anonymous reviewers, and participants in the Boston Area Religion group for comments on earlier drafts. Many thanks also to Robert Wuthnow, Sister Margaret (Meg) Funk, and all of the women interviewed.
} 
In the American context, some historians and sociologists have focused on the vast degree of hybridization that occurs at the level of lay practice (Roof 1993; Wuthnow 1998; Coleman 2001; Carroll 1999; Hall 1997; Orsi 1985). Others have emphasized how some religious communities-especially immigrant communities_-adapt their theologies and organizational structures in the face of new religious-institutional environments (Warner and Wittner 1998; Ebaugh and Chafetz 2000). In this paper, we pay attention to a third ongoing site of religious hybridization and change: religious interaction and appropriation among committed religious professionals. We draw on interviews with senior Buddhist and Catholic nuns who participated in an interreligious dialogue to explore how Buddhism was understood and constructed in these interactions and to develop insights about the impact of such interactions on Buddhist and Catholic selfunderstandings.

Our focus on how religious professionals in the United States construct and practice Buddhism is of particular import given longstanding interest in how Asian religious traditions are used and changed in the American context. Scholars have long noted Americans' infatuation with Buddhist ideas and teaching and how such historic interchanges have shaped both Buddhism and American Christianity (Prothero 1996; Tweed 1992; Batholomeusz 1994). While much of the current mixing and influence stems from the growing number of Buddhist organizations in the post-1965 period (Cadge 2005; Seager 1999; Prebish 1999; Prebish and Tanaka 1998; Williams and Queen 1999), other recent research shows that much of Americans' encounter with Buddhism is selective and emphasizes particular Buddhist practices, namely meditation (Swearer 1995; Harvey 1990; Layman 1976; Prebish 1979; Tweed 1999a; Tweed 1999b). A recent national survey shows that a great deal of mixing occurs outside of Buddhist institutions: few of the 27 million Americans who report being influenced by Buddhist teachers or ideas have ever visited a Buddhist organization (Wuthnow and Cadge 2004). While some argue that these examples highlight numerous ways Buddhism is being lived across the country, other scholarly observers have been critical of piecemeal, non-institutionally grounded appropriations, arguing that they share more in common with seeker spirituality than with the "Buddhist tradition" (Carrette and King 2004; Miller 2003).

Within studies of Buddhism in America and religious appropriation more generally, scholars have paid little attention to how religiously committed Christians and Jews draw on Buddhism and to the impact of interreligious interactions between religious professionals. This arena of interaction is important because American Protestant, Jewish, and Catholic leaders have been active participants in such dialogue, often with strong institutional backing. Contact between Catholic leaders and Buddhists has a long tradition, particularly through Jesuit missionary activity and the pilgrimages of well-known individuals like Thomas Merton. Beyond this, the Vatican initiated "monastic dialogues" between Asians and Catholics in the 1970's with the express purpose of building 
a "bridge between religions" (Perron 2005; Borelli 1999; Mitchell and Wiseman 1999). In addition, many Jewish and Christian religious professionals continue to draw on Buddhist forms and ideas to revive or re-imagine contemplative practices in their own traditions (Cadge and Bender 2004; Klassen 2005) that they then teach to others.

In this paper we analyze interviews with senior Catholic and Buddhist nuns who participated in an interreligious dialogue to understand how committed Catholic religious professionals adopt Buddhist teaching and meditation practices. After discussing the Buddhist practices of both the Buddhist and the Catholic nuns, we outline three ways that "Buddhism" is constructed by Buddhist and Catholic nuns, and then analyze how these various constructions are used and continue to work within religious traditions and within the numerous conversations between Catholics and Buddhists. Our analyses suggest not only that Catholic engagement with Buddhism is constructing and shaping Americans' views of "Buddhism," but that these constructions develop together, as Buddhist and Catholic nuns come to understand their unique historical positions through imagining and engaging the other.

\section{RESEARCH METHODS}

This article is based on interviews with twenty-one of the thirty Catholic and Buddhist nuns who attended a three-day interreligious dialogue in 2003 held at a Buddhist temple in California and hosted by one of the senior Buddhist participants. Participants represented the Benedictine (8 sisters), Maryknoll (2), Sisters of Providence (1), Religious Sisters of the Sacred Heart (1), Congregation of Notre Dame (1), and Catholic Orthodox (1) orders and the Soto Zen (5), Fo Guang Shan (2), Thai Forest (1), Tibetan (3), Korean, (3) and mixed/combined (2) Buddhist traditions. These nuns were invited to participate in this dialogue primarily because they were in the personal networks of the organizers. All of the nuns spoke English, were fully authorized in their own tradition, and had the time and permission of their superiors to attend. The dialogue took place without a formal agenda, papers, or outside observers. Issues discussed included the contemplative life, the balance between contemplation and social action, and the importance of religious training, community, and tradition.

Following the dialogue, each participant was invited by postcard, letter, and telephone to participate in this research project. All but one of the Catholic nuns participated $(\mathrm{N}=13)$. Only nine of the sixteen Buddhist nuns participated representing the Soto Zen (4), Tibetan (3), Fo Guang Shan (1), and mixed / combined (1) Buddhist traditions. Some Buddhist nuns did not participate because they were on long meditation retreats while others were uninterested or simply not reachable following the dialogue. We conducted interviews with all of these women by telephone. Interviews lasted between one and two hours and included questions about each woman's religious tradition and life story as well as her 
experience of the commonalities and differences in monastic traditions, the relationship between contemplation and action in the world, and her experiences in interreligious dialogue. While we did not attend the dialogue itself, nuns freely discussed what happened there during the interviews. With the exception of the Korean Buddhist nuns, interview participants are representative of dialogue participants. They included some of the most senior Buddhist and Catholic nuns in the United States.

The majority of nuns interviewed were born in the United States. All but two Catholic participants were cradle Catholics born in the 1930s or 1940s who took vows in the pre-Vatican II era. All were highly educated: among the Catholics four held PhDs and eight held masters degrees. Eight of the thirteen Catholic nuns interviewed live in monasteries or religious communities; most of these communities are experiencing rapid decline in membership and population. The Catholic nuns who do not live in large communities live with one or two other nuns or (in one case) alone. Only one of the Catholic nuns interviewed wears a habit, although all dress modestly and simply in accord with their orders' guidelines. All of our Catholic respondents structure their lives in conformity to community rules and schedules.

The majority of Buddhist nuns were born into non-Buddhist families. Seven were born in the U.S. and five were raised in Christian homes. They were generally between age forty-five and sixty-five. Most were ordained in their thirties and several had been married and / or had children. More than half of the Buddhist nuns interviewed had some graduate training. Several hundred Buddhist nuns currently live in the United States (see Tsomo 2002), either on their own or in one of several Buddhist monasteries. These nuns are members of various lineages or sections of the Buddhist tradition which have different rules and prescriptions but generally stipulate that nuns not be married and that they follow certain guidelines in their dress and behaviors. About half of the Buddhist nuns interviewed live at monasteries while the other half live alone, generally because there are so few Buddhist monasteries in the United States.

The Catholic and Buddhist nuns in the dialogue exhibited a high level of demographic similarity, which seemed to provide a level of affinity and connection in the dialogue. One Catholic nun said, "I always have a lot of respect for people [whom] I know have paid their dues." She recognized that the others had also "suffered something really tough and they've come out of it a better person or a more compassionate person." A Buddhist nun echoed this, saying, "To be a nun... I think you've got to be fairly independent and strong." While she recognized the great differences in life experience between the two sets of nuns, nonetheless "it just seemed to me that all the women that were there-the sort of group of us-they knew where they were going." Participants identified their central shared characteristic as a commitment to a vowed, normally celibate life, though their understandings of their spiritual or religious lives surrounding that commitment varied within and between traditions. Strikingly, almost all of the 
participants, Buddhist and Catholic, also shared commitment to some kind of Buddhist practice in their daily lives.

\section{BUDDHIST EXPOSURE, TEACHINGS, AND PRACTICES}

\section{Exposure to Buddhism and Training}

Books, courses, specific teachers, and time spent in Asia were the main conduits through which both the Catholic and Buddhist women encountered and learned about the Buddhist tradition. One Catholic nun said she "just read a bunch of books" initially, as did at least one Buddhist nun interviewed. Another Buddhist nun raised in a Christian home explained, "I had a friend, I guess, who was interested in Eastern religious and I started reading from her books. ... Buddhism made a lot of sense to me." Many Buddhist nuns traced their interest to their childhood or young adulthood while, the majority of Catholic nuns said that their interest in Buddhism arose after they were vowed.

Many Catholic and Buddhist nuns contacted a Buddhist organization or teacher, or began to attend meditation classes or retreats, after reading about Buddhism. Buddhist nuns typically contacted visiting Asian-born Buddhist teachers. Catholic nuns, in contrast, often learned about Buddhism through contact with Catholic priests and religious laypeople who claimed an affiliation with both Buddhism and Catholicism, although several learned about Buddhism through travel or work in Asia. Catholic nuns told us of taking meditation classes led by Jesuit priests who are also Buddhists and in one case a Benedictine nun who is also a Zen master. One Catholic nun attended her first Zen retreat a decade ago and now studies with a Japanese-trained roshi who is also a Jesuit priest. "He went to Japan as a missionary," she explained, "and several of the Jesuits started really meditating with the Zen Buddhists in Japan."

The historical forces set in motion after Vatican II likewise promoted conditions in which some of our Catholic respondents sought out Buddhism. Vatican II reforms required all Catholic orders to scrutinize their habits and practices and develop a stronger sense of their community's purpose (Ebaugh 1977; Wittberg 1993; Wittberg 1994). This process, several nuns told us, woke their orders up to the "emptiness" of their devotional practices, dress codes, daily habits and community life patterns. Religious orders were thrown into a state of disequilibrium and searched for ways to live out their congregations' underlying "charism." As one of the nuns told us,

... we simply kind of realized that we were without a base and what we were missing was the deeply contemplative piece of our lives. And then we began to search around for what that meant and where it was. And ...we were free to do this, because of all the changes that had gone on ... to go to different seminars, to search around for different gurus, to see who could help us find what it was that we suddenly had discovered... we were missing. ... I didn't know what I was looking for, but I knew that I wasn't satisfied with what I had.. 


\section{SOCIOLOGY OF RELIGION}

Although the Catholic nuns experienced varying levels of personal dislocation in this period, all of their communities underwent radical changes. "We had gotten rid of all the old rules, but there wasn't much in place," one said in a phrase echoed by others. A number of orders began to seek out guides for how to become more contemplative, some turning to "centering prayer" and others to Zen and vipassana meditation. While one Benedictine nun told us that some orders and communities "never lost" their "core" contemplative practices, even those that remained relatively stable began to consider sources outside the Catholic tradition, including Buddhist ones. Doing so, however, raised questions about the relationship between Buddhist meditation "forms" and Buddhist philosophy, discussed in more detail later.

The majority of Buddhist nuns at the dialogue had extensive training and instruction in Buddhist organizations in Asia, and all maintain formal ties to these organizations through ordination. Those ordained as priests (the term they prefer to nuns) in the Soto Zen tradition, for example, spent more than a year progressing through a series of specific categories in their training and ordination in Japan. In contrast, nuns in the Tibetan Buddhist tradition do not have access to full ordination in the Tibetan Buddhist tradition, so after receiving their teachings and first level of ordination (novice ordination) in the Tibetan tradition, they then received higher or full ordination through teachers in the Taiwanese, Korean or Vietnamese Buddhist traditions (Tsomo 2002; Tsomo 2000; Chodron 2000; Li 2000). Thus, while all of the nuns learned about Buddhism in multiple ways, the majority of Catholics had comparatively little exposure to Buddhism in Asian Buddhist institutional contexts. These differences are apparent in the how dialogue participants understand Buddhist practice.

\section{Buddhist Practices}

As noted, about half of the Catholic nuns consciously practice Buddhist meditation on a regular basis. As one explains, "I sit in the morning before I go to work and really before I get dressed. I sit not much more than a half an hour daily but on Wednesday morning I go to the 5:30 sit [in a regional] zendo... and so I sit in the zendo for the day, not always the day, maybe until noontime, after lunch or something." She also occasionally attends day, weekend or all week sessions at the zendo. Another Catholic nun has done sitting meditation daily for the last twenty-odd years by sitting on the floor on a zazen cushion and focusing on a word to calm her mind. Several of the Catholic women religious described such practices as "Christian Zen," a fusing of Christian teachings and symbols with the "form" of Zen meditation. Some practice alone; one has meditated for twenty-five minutes before her community's morning prayers for the last two decades. Others do it in groups; one described the meditation she does with a few friends once a week as "Christian Zen," or "a liturgy of shared silence," and another described her community's commitment to "contemplative sitting practice" or "Christian Zen" for two hours and twenty minutes each day. 
Buddhist influence is further evident among those Catholics who engage in "centering prayer," a practice developed by a Cistercian priest and monk Thomas Keating. One respondent described it as "simply an opportunity to be quiet, very quiet," saying, "the breath practices are the important thing. You breathe Christ in, you breathe Christ out, you breathe the Spirit in, you breathe the Spirit out. It becomes a kind of-a non-thinking place for you so that you can be comfortable in not thinking. It's hard. It is very simple." The Catholic nuns who teach centering prayer often encourage practitioners to focus on a sacred word as a way to calm the mind while focusing on the breath, an idea borrowed directly from Buddhist meditation practices and mantras.

Buddhist nuns, in contrast to the Catholic respondents, discussed Buddhist teachings as part and parcel of their lives, which often conform to a Buddhist monastic schedule, rather than focusing on specific practices. Those who live in monasteries and / or with other nuns or monks typically meditate, chant, or do prostrations and make offerings several times a day. One explained, "We sit in meditation every morning here. We have first a morning meditation and then we have a morning ceremony, and then we gather and say 'Good morning,' and then I go about my day." A number of the Buddhist nuns sought to erase the distinctions between Buddhist or religious practice and life outside of them, seeing it as all one. As one Zen Buddhist explained, "Certainly, there's practice all of the time. It's not just that we do the cleaning but how we do the cleaning, how we do the cooking... So it's not like it's just that one hour, but the one hour tends to be more academic and then should feed the rest of the day."'

\section{CONSTRUCTING BUDDHISMS}

The relationship between Buddhist forms (sometimes called "tools," "techniques" or "externals") and the content of Buddhist teachings and philosophical systems was central to the three main ways that the nuns who were interviewed understood the Buddhist tradition. We identify these three approaches as "constructions." One construction, which we heard primarily from Catholics, implies that Buddhist forms and contents can be separated: in this construction Catholics and Buddhists can both "use" the form and remain true to their traditions. A second construction, which both Catholics and Buddhists drew upon, likewise distinguishes between Buddhist form and content, but sees these two parts as inexorably linked, so that people who "use" Buddhist forms are either in the process of becoming Buddhist (whether they see it that way or not) or are

'The Buddhist nuns interviewed were generally uninterested in learning about Catholic monastic life. Aside from one Buddhist monastic community that had set Buddhist lyrics to traditional Christian hymn tunes, there was little evidence among these women that Catholicism has had the influence on Buddhism that Buddhism has had on Catholicism. 
misusing/misappropriating Buddhist forms. The third construction, which we heard primarily from Buddhists, rejects the idea that form and content are separate. This position emphasizes that meditation "form" itself cannot be separated from Buddhism (understood as a way of life in which contemplation and action are always one and the same), suggesting that those who try to do so are not in fact practicing anything "Buddhist" to begin with.

\section{Constructing Buddhism as Form}

A number of Catholic nuns emphasized the positive inclusion of Buddhist forms in extending and deepening Catholic contemplation. One Benedictine nun remarked, "we have had the contemplative tradition and understandings. [You can] go back to any of the mystics and teachers of our tradition-they're so beautifully there. But we haven't had the practices to embody it and I think that's where the Eastern religions have helped us. Something like a sitting practice helps me to imbibe my own tradition." She continued, remarking on how little attention the Catholic contemplative tradition places on form.

[We] have something like to Cloud of Unknowing, which teaches the contemplative prayer. Certainly seeking some quiet and what to do mentally and how to handle socalled distractions, are all in there. But the exterior practice I think, or saying and doing this, the frequency, and the posture, and breathing techniques, and this sort of thing... [they aren't there]. And so [we] have these examples but [we] don't have a teaching that we have automatically been taught in our catechism classes.

A number of the Catholic nuns echoed this, stating that "Eastern traditions" could provide a technology for meditation, including methods of stabilizing the breath or heartbeat, or learning how to "tranquil down the fragmented mind." One claimed that "Eastern traditions" taught her "that we need to have a form." The nun who sits each week for a day at a local zendo described her practice in this way: "Zen teaches you to breathe in and breathe out and breathe in and breathe out and let everything else go, no thoughts, let your feelings go, just really let it go, so I just got this sense of silence and quiet ... but I think what I've learned from Zen is to be present, to be aware."

While most of the Catholic nuns were at least somewhat sensitive to the idea that such "forms" are parts of whole Buddhist religious and philosophical systems, most also suggested (and their practice demonstrated) that these forms can be adapted to Christian worldviews. One Benedictine nun whose community sits corporately and ends its group meditation with a chant and a ringing gong called that practice "Christian Zen," explaining that it can be so called "because Zen is not theistic, so if you're seeking union with God you're automatically right away interested in something else. So it needs to be adapted." When pressed to define what makes the experience "Zen," she emphasized its form, "in the sense that the externals are Zen. For now we call it Zen, the practice." These emphases on the external forms of meditative practice focused primarily on the embodied aspects 
of meditation, including the body's shape and posture, and went hand in hand with an understanding of Buddhism as non-theistic, and therefore not closed off to those who wish to employ it in theistic devotional practice and prayer.

While we heard many Catholic nuns speak of Buddhism as "form," it is important to note that Buddhist respondents were also comfortable with learning from various meditation forms. Because of their participation in Buddhist institutions, however, they tended to discuss this variety as participating in different "traditions" rather than "practices." One Buddhist nun, for example remarked that the positive part of being a Buddhist nun in the United States was that it afforded "exposure to so many different styles [of Buddhism] and faiths. I mean, if this were a hundred years ago, in central Tibet, I'd probably be practicing a very specific style, whereas, here, in the West, we have exposure to all the different traditions...." Another explained, "every [Buddhist] tradition has jewels...there is no conflict...I gain tremendously from each.... I think that each of the traditions has special gifts to offer."

\section{Constructing Buddhism as Form and Philosophy}

A number of the Buddhist nuns were troubled by the distinction between Buddhist meditation forms and the teachings and traditions connected to those forms. One Zen participant was most outspoken on this issue, saying,

What I feel, on occasion, is the sense of having my tradition co-opted [by Catholic friends], and feeling very uncomfortable with that. One question to me was, 'Okay, if I can fully practice Zen, how can I apply that to the Trinity?' Well, you can't! I mean, not from my mind you can't. So, there's a sense of co-opting, wanting to co-opt the very central experiential piece that one can only experience by giving up everything in totality.

Echoing this view, one Buddhist nun reflected on how a focus on forms relates to the ways that Buddhism is adopted in American society: "I'm somewhat concerned that in western countries, people may begin to just sort of take those bits and pieces that they find comfortable and sort of leave the rest of the tradition, where in my view, it's part of an organic whole," she said. Practice without understanding the Buddha's teachings or considering the precepts that accompany these practices is missing the point. By understanding meditation forms as tools, these Buddhist nuns see the Catholic nuns participating in the very same American picking and choosing they often encounter among their students and are trying to overcome in their teachings about Buddhism as a holistic religious / philosophical tradition.

Several Buddhist nuns wondered why the Catholic nuns were looking to them for forms, and what this might mean about the state of the Catholic tradition. One Buddhist nun questioned whether the Catholic tradition lacked wholeness: "The thing that was the most fascinating about [the dialogue] was that the Christian nuns were looking to us to help them." She said that she "felt concerned for them," especially since they didn't seem to have any Christian 
contemplatives to "look to, to help them figure out what would be right for them, other than maybe say Thomas Merton or somebody like that."

While the Buddhist nuns were comfortable talking about the forms of practice that they do as practice, they nonetheless argued that uncoupling practice from the Buddha's teachings, or from the philosophical frameworks in which they developed, is not possible. "I think that at one point their [the Catholics'] question [in the dialogue] really was, 'How can we get what we think you have?" one Buddhist nun told us, adding, "We said, 'Well, give up everything. Give up everything, you know, give up all your doctrine and everything you believe and try and find it.' Which is what we did."

These tensions were not wholly lost on the Catholic participants. A number of the Catholic nuns also expressed concern about whether it is possible to borrow Buddhist meditative practices without also drawing in Buddhist teachings and philosophy. Some echoed the Buddhist nuns, and called for Catholics to be more aware of what Buddhist teachings entail. One of the sisters who practices Zen meditation hypothesized that one reason Buddhist traditions appeal to Catholics is that so few Catholics know much about their own philosophies. "There seems to be more ease with something that's totally foreign than with something that's maybe closely related," she explained, suggesting that the lack of knowledge about Buddhism allows for a certain type of projection among the curious about what it might be. She continued, "I can't say the [Catholic] sisters, even those who have practiced it [Buddhism], are particularly knowledgeable ... It's the whole philosophy and theology of the Eastern traditions and I don't think they are very knowledgeable about."

Another Catholic nun responded to the same issue with a laugh, "I just get the impression sometimes that we Westerners now are all gaga over Easterns [sic] and it's like, 'Oh, no the Western tradition has nothing to teach us. Everything has got to come from them." Another Catholic nun echoed this perception of the dialogue, saying that while she thought that Catholics had much to learn from Buddhists, she did not believe that Buddhist meditation practice would offer much to Catholics. "We can learn the way Buddhists do things, but I'm not sure we can say we ought to imitate that and do it the same way, because the motivation for doing it is quite different." She said, "If you're really thinking about meditation techniques, which has to do with how you believe you are related to the divine, I'm not sure we can learn much from each other."

Several Catholics likewise pondered how adopting a Buddhist practice might influence Catholic identity: does "practicing Buddhist meditation" makes one a Buddhist, a practitioner of another Asian religion, or perhaps more importantly, not a Catholic? One of the nuns was troubled for many years that her yoga practice was, as some had told her, "of the devil." Likewise, the Catholic respondent who was the strongest proponent of learning from Buddhist forms nonetheless believed that each tradition's practices can require allegiances that draw the religious person in different directions. After she retired as her community's prioress, 
she studied with spiritual teachers in several Asian traditions but then as she put it, came back to Christ very "tired." She explained, "I know first hand ... [that] we can't keep crossing over through these lineages and not be enormously [affected] ... " She remembered, "I had a kind of a crisis, and I probably had kind of a vision as it were of Christ and Christ saying, 'You know, it's time to come back, let's just get back together, again. Single minded, my tradition, you and me. Stay with the Benedictines here, in this little place." She now spends her time as a spiritual director, teaching Lectio Divina, a Catholic contemplative practice taught in Benedictine communities, in the U.S. and Europe. She says, "I think our novitiates should be much more practiced in stability of the mind, training of the mind .... And we really should do them in our Christian context... because when you go East ... you've got to go to the chain of sensibility, or making sense of taking refuge in the Buddha ... and you lose your Christian identity."

While a growing awareness of the depth of theological differences between the various traditions led this Benedictine nun to be singled-minded in her return to the Christian tradition, similar awareness has prompted others to consider the possibility of "multiple belonging." One Catholic nun who identifies as a multiple belonger said that "in the heart of these traditions... a profound... spiritual wealth that needs to be looked at, needs to be learned. Each one has a very profound truth and access to God. To flit around is, would be, to be a dilettante. I think it's important to go deeply, really deeply, into different traditions, and maybe come out, as ... a multiple belonger, I've been thinking about multiple belonging as a Christian, and a Buddhist, and I'm not sure that I know enough about Buddhism, but I'm trying to go more deeply and really study it."

\section{Constructing Buddhism as a Way-of-Life}

While the two constructions noted above separate form from content or philosophy (albeit the first in a more radical fashion) a third tries to "eras[e] the line" between contemplation and action, and in so doing works to displace emphasis on the particular worth of the forms of meditation outside of Buddhism as a way of life. This construction emerged most clearly as Buddhist nuns discussed their approach to the Buddhist tradition, specifically the relationship they see between contemplation or meditation and their broader actions in the world. "I don't see my daily life as something separate from my meditation or my meditation as separate from my daily life," one senior Buddhist nun told us. While she "has time for both," she doesn't think about moving "back and forth" between them, but rather sees them as "interconnected."

All of the Buddhist nuns based their religious or spiritual lives in some way in their personal meditation practices, although like the nun quoted above, they do not all draw clear distinctions between these practices and their lives off the cushion. One Zen participant stated in a similar fashion that her practice was what happened "off the cushion." "... getting up off the cushion is really where practice is. So I'm fully engaged in the world." Another Zen participant similar- 
ly challenged the distinction between meditation and working in the world. "I don't think that, when a person goes off into an extended retreat, they're leaving the world-not in Zen. In other traditions, maybe yes, but it's not my understanding of the Buddha dharma from a Zen perspective. My teaching is very much about integrating them, so people come and say, 'What's the relation of zazen'- the sitting practice - 'to daily life?'... I teach it as an activity of daily life and as a paradigm activity that can influence the rest of your daily life and that we're not trying to somehow come out as sort of zazen zombies into the world So, I'm trying really to dissolve that-that there is only one universe, one life, and one person here and that we cannot have a coherent and continuous sense of life, which is really what awakened life would be like..."

While some of the Buddhist nuns modeled engagement with the world through their activities with non-Buddhists outside of Buddhist centers, others spoke quite clearly about how being deeply committed and involved with teaching and practice at a Buddhist center can itself erase these distinctions. One nun, for example, was quite emphatic that her primary responsibility was to teach contemplation. "We're really contemplative. We don't go out taking care of the sick and that kind of thing. We do teach Buddhism... And if people want to come here and practice, this is our work for the world." In her commitment to Buddhist teaching and practice, this nun sees herself helping to eradicate the very distinctions between self and other, form and content, which truly eradicate suffering as outlined by the Buddha. Making the comparison more precise, another nun noted that the distinctions among Catholic orders, where some are more focused on contemplative practice and others more focused on active practice, does not hold in Buddhist monasticism or philosophy. "A Buddhist nun, we can live in many different lifestyles while-as long as we keep our vows." In this discussion and in others, Buddhist nuns worked to offer a very different perspective of Buddhism and monastic "practice" than what they understood the Catholics to be saying in their emphases on more de-contextualized Buddhist forms.

\section{INTERPRETING CONSTRUCTIONS: BUDDHISM(S) IN DIALOGUES}

To more fully understand why Buddhism was constructed in these three ways, it is important to recognize how these constructions emerge from other "dialogues" in which the nuns participate, including intra-Catholic dialogues about the meaning and possibility of Christian contemplation, and intra-Buddhist conversations about the shape and future of Buddhism in the United States.

\section{Constructing Buddhism in Catholic-Catholic Dialogue}

The idea of Buddhism as form has played an important, almost idealized role as evident here in some Catholic nuns' reappraisals of their traditions, their ongoing attempts to balance contemplation and work, and their visions of their 
orders' futures. Buddhism arose as a contrasting, somewhat idealized tradition in which monastics are devoted to contemplation and not focused on the "busyness" of life. Sounding a refrain that we heard through most of the Catholic interviews, one Benedictine nun told us that her order's motto, "Ora et Labora" (pray and work), should be "Ora et Labora et Labora et Labora," given that work is never done, and sometimes prayer takes a backseat. Another Benedictine complained that the "Protestant work ethic" is "alive and well" in her monastery. When asked what stands in the way of contemplative life, she said, "the busyness.... I like to blame the community and the culture, but it's all in my skin too."

The struggle to balance work and prayer was heightened for the generation of Catholic nuns who pursued their vocations in the wake of Vatican II when the council gave each order a charge to review its purpose and rethink the reasoning behind its commitment to particular external forms. One of the Catholic nuns told us "we've been called up to transform [our order]. We're called on to preserve the best and the deep values of religious life, but [also] literally to transform it. [It] has been an enormous challenge for us." This challenge was accompanied with new freedoms to search out non-Christian practices, and likewise with a new suspicion of long-standing Catholic practices, including the rosary and other devotional practices.

The declining numbers of Catholic women religious in the United States, and the post-Vatican II changes that permitted lay-and non-Catholics to work in Catholic institutions once run exclusively by Catholic orders, also prompted Catholic orders to rethink their roles and futures. Indeed, while most of the Catholic nuns we interviewed have held positions teaching in Catholic schools or administrating hospitals or schools, most now teach within their communities or are otherwise engaged in spiritual formation and counseling, or in administering retreat centers. Such biographical and congregational realities shape the context in which conversations with Buddhist monastics emerge.

These shifts in Catholic practice have included adopting Buddhist "practice," in which Buddhism appears as a tradition in which contemplation is a much more central concept than in Catholicism. Catholic nuns "think with" constructions of Buddhism as form that help them work toward specific goals, including invigorating and reviving elements of Catholic contemplative life. One Catholic nun noted that "practice" is one thing that Buddhist and Catholics have in common, even though she thinks the "Buddhist nuns often reflect on the practices and less so on the good work and charity that follows from this." Continuing the comparison, she said "whereas the Christian nun is very ... much aware of the prayer, but also the work and charity that flows from it .... We all wanted a little more of what the other had."

This idealization of Buddhist contemplative life was further evident in the Catholics' comments about the Buddhist nuns' living arrangements. Rather than recognizing structural factors that limit Buddhist nuns' opportunities for communal living, the Catholics' gently criticized what they interpreted as Buddhists' 
choices not to live in communities. One Catholic observed, "I was surprised that we didn't have more in common in terms of community life. Most of the Buddhists lived alone, it seemed to me. And that kind of surprised me, because I had thought community life was a pretty important part of monasticism in any tradition." Another Catholic compared her order's compulsion to community living with a Buddhist nun friend's solitary life: "although [my Buddhist friend] is not a hermit, she spends a lot of her time not in a particular community. Theoretically, she's attached to a community, to a tradition, but she's not limited. If she feels the call, she can set herself up almost anywhere. And, as she says, her monastic life is-she's like a turtle. It's right on her back; she carries it with her. And this would be practically impossible for me." With this perception in place, Catholic nuns further related individual living of Buddhism to what they viewed as the roles of solitary, individual Buddhist contemplation practices.

Catholics nuns' perception of the difficulty of practicing spirituality "without" a community and their view of Buddhist nuns as individual practitioners shape some Catholic nuns understanding of what nuns from both groups bring to and gain from interreligious dialogue. Catholics, in fact, mentioned several times that they had insights into institution building in the United States, and thought that this information and experience might be useful in an exchange with Buddhists. Said one Catholic, "The Catholic sisters [are] tending to recognize the need for contemplation, a lot more contemplation, along with their social activities, whereas the [Buddhist] nuns, they were seeing that they needed to get out to have more social action with their contemplation." In constructing this comparison Catholic nuns also articulated what they had to share as ideas and traditions of communal living. The Buddhist nuns, with a different perception of communal living in relation to their tradition, did not share this view.

\section{Buddhism in Buddhist-Catholic Dialogue}

The nuns who participated in this dialogue are among the first generation of Buddhist nuns in the U.S. and, as such, are engaged in the process of defining the Buddhist tradition here. Arguments about their responsibilities for defending Buddhism as a whole tradition emerged as a result of their role as tradition builders. "Part of my job as a priest [nun] is to protect the [Buddhist] tradition," one Buddhist nun told us. This she said was quite different from the job of the Catholic nuns, who enjoyed a much stronger institutional position in the United States. Coupled with the responsibilities that come with being the first generation of Buddhist women monastics is the fact that she and the other Buddhist participants are themselves converts to Buddhism who, at least at this stage, spoke about being largely content with the tradition, not in search of something more to fulfill their religious or spiritual lives. As she explained, "You know, all of us [Buddhist nuns] seem to be incredibly content in our practice and not feeling that we're searching for something outside of it. And I have a feeling that my tradition completely satisfies me. I don't need to look to any other tradition for 
pieces to make up for what I think is missing. There is nothing missing for me."

Such concerns voiced by the Buddhist nuns extend beyond the scope of this dialogue and highlight the ways in which Buddhist nuns in the U.S. are also participating in constructing Buddhism. Arguing that Buddhism is a tradition and not "just" meditation highlights the degree to which such an idea has been present in American society, and is likewise embedded in various "meditation" centers and classes, how-to books, and the rise of Christian and Jewish "Zen" masters. It is important to note, therefore, that Buddhist nuns are forcefully engaged in constructing an "authentic" Buddhism that will be viable in the United States and serve as a corrective to piecemeal appropriations. The future of monastic Buddhism in the United States is being shaped by these constructions and dialogue.

The Buddhist nuns' emphasis on Buddhism as a whole tradition raised further concerns about all participants' lack of basic knowledge about the other tradition. For a Catholic-Buddhist dialogue to move "forward," one of the Buddhist nuns argued, it would have to be built on participants' deeper study and more holistic understanding of the traditions rather than to focus on what nuns "share" in terms of external forms, relations to religious hierarchies, or personal life stories. Rather than allowing the "misunderstandings" evident between traditions in this dialogue to continue, she explained "my feeling is that we need to provide in-depth forums ... to sit down and really explore where our philosophical common ground is and where we've got major differences." A number of Catholic nuns echoed this concern, with a few saying that they recognized that the Buddhism they learned about in books was different from what their dialogue partners practiced and professed.

From this deeper understanding come two observations that underlie Buddhists constructions of Buddhism in dialogue with Catholic women religious. First, the relatively recent arrival of Buddhist monasticism on American shores and its lack of established institutional structures leads no one person or organization, in this dialogue or elsewhere, to speak authoritatively for Buddhism, hence some of the Buddhist nuns' conservatism and desire to "defend" a tradition. Second, the Buddhism many of the Buddhist nuns' envision develops under different historical and structural realities than that experienced by Catholic religious orders. This leads toward a construction of Buddhism as "all of life," that challenges the distinction between Buddhist content and form heard in conversations both at the dialogue and elsewhere in American society.

\section{CONCLUSION}

This interreligious dialogue provided a rich site in which Catholic and Buddhist women engaged in complex conversations about their own tradition and the other. Although not the central purpose of the meeting, Catholic and Buddhist interaction nonetheless actively articulated and shaped various con- 


\section{SOCIOLOGY OF RELIGION}

structions of "Buddhism." These various constructions are not unique to the dialogue itself, but were rather mobilized within it in ways that allowed us to better understand how Buddhism is lived and constructed by religious professionals in both traditions. This example, then, presents several challenges and ideas for future consideration that arise as we understand how participants in the dialogue shaped their understanding of their own tradition and the others' simultaneously. Dialogue, we should note, is always full of imprecise translations and misunderstandings. This is certainly the case in this example. Nonetheless, nuns often seemed to be talking at cross purposes despite their endeavors to deepen their connections with others. This is because, at one level, the dialogue was marked from the outset by constructions of Buddhism that had already taken hold in various intrafaith contexts and practices. In other words, while Catholic nuns practiced Buddhist meditation in Catholic contexts, their practice and understanding of Buddhism was similarly likely shaped by concerns and struggles of religious practice that were internal to their own religious communities. Drawing the "context" a bit more broadly, the same could be said for Buddhist nuns in the United States who teach and live Buddhist lives in a setting where "Buddhism" is already marked and defined, albeit not in ways that are particularly felicitous in the view of Buddhist nuns.

These observations highlight several further questions and paths for future research. First, this example suggests that discussions of appropriation and mixing of religious traditions might focus more attention on the role of religious elites and leaders (Cadge and Bender 2004; Klassen 2005). Catholic nun's Buddhist practices challenge commonsense schemas in which Americans interested in Buddhism are either converts or dabblers (e.g. Tweed 1999a), and which view transformations in Buddhist organizations in America primarily occurring through responses to broad structural challenges (e.g. Ebaugh and Chafetz 2000). The importance of leaders' understandings is made more pertinent when we consider that most of our Catholic respondents are active teachers, lecturers, and spiritual guides. More investigation is needed to understand the "Buddhism" transmitted in these settings, and how such pursuits might pose real challenges for Buddhist and Catholic dialogue.

Second and related, this dialogue highlights the degree to which Buddhist leaders also define and teach Buddhism in light of their perception of the other. In this case, nuns focused on how Buddhism is misperceived by Americans, a view that was evident in their criticisms of Catholic nuns' practice. While Buddhist nuns also talk about a variety of "traditions" and "practices" that inform their own religious identities and life journeys, when talking with Catholics they emphasize a "whole Buddhism." This discourse is both a response to dilettantism, and a product of a long history of contact between Buddhists, Catholics and Protestants in Asia and America (Prothero 1996; Stirrat 1992; Bartholomeusz 1994). 
The observations that Buddhist and Catholic women simultaneously construct in their own self-identity and in the identity of the other underscores the degree to which all religious traditions are constructions built in relation to internal and external relations, both real and imagined. As such, the circulating stories and constructions are often hard to pull apart, and challenge academic definitions of a "pure" or "authentic" religious tradition that can be used to judge or analyze any particular lived expression of that tradition. Catholic nuns' visions and understandings of Buddhism and Buddhist practice are refracted through their own deepest concerns about their lives as Catholics. Buddhist nuns engaged a similar process, insofar as they constructed their experiences as Buddhist nuns through unequally shared understandings of Catholicism and Buddhism. Nuns' mobilizations of various constructions of Buddhism in the service of numerous ends suggest that we must broaden our understanding of hybridization further than the striking example of Catholic nuns' uses of Buddhist meditation forms. "Hybridization" and mixing also occurs in entrenched and ongoing social processes (Stewart 1999) wherein religious groups and individuals live and experience their own histories and religious selves through dynamic engagements with religious others.

\section{REFERENCES}

Bartholomeusz, T. 1994. Women under the Bo Tree: Buddhist nuns in Sri Lanka. New York: Cambridge University Press.

Biernatzki, W. E. 1991. Roots of acceptance: The intercultural communication of religious meanings. Rome: Pontificia Universita Gregoriana.

Borelli, J. 1999. Buddhist-Catholic Retreat/Dialogue. Buddhist-Christian studies 19:191-92.

Boyarin, D. 2004. Border lines: The partition of Judeo-Christianity. Philadelphia: University of Pennsylvania Press.

Butler, J. 1990. Awash in a sea of faith: Christianizing the American people. Cambridge: Harvard University Press.

Cadge, W. 2005. Heartwood: The first generation of Theravada Buddhism in America. Chicago: University of Chicago Press.

Cadge, W. and C. Bender. 2004. Yoga and rebirth in America: Asian religions are here to stay. Contexts: Understanding people in their social worlds 3:45-51.

Carrette, J. and R. King. 2004. Selling spirituality: The silent takeover of religion. London: Routledge.

Carroll, M. 1999. Irish pilgrimage: Holy wells and popular Catholic devotion. Baltimore: Johns Hopkins University Press.

Chodron, B. T. 2000. Western Buddhist nuns: A new phenomenon in an ancient tradition. In Women's Buddhism, Buddhism's women, edited by E. B. Findly, 81-96. Boston: Wisdom Publications.

Coleman, J. W. 2001. The new Buddhism: The western transformation of an ancient tradition. New York: Oxford University Press.

Ebaugh, H. and J. Chafetz. 2000. Religion and the new immigrants: Continuities and adaptations in immigrant congregations. Walnut Creek: AltaMira Press.

Ebaugh, H. 1977. Out of the cloister: A study of organizational dilemmas. Austin: University of Texas Press. 


\section{SOCIOLOGY OF RELIGION}

Hall, D., ed. 1997. Lived religion in America: Toward a history of practice. Princeton: Princeton University Press.

Harvey, P. 1990. An introduction to Buddhism: Teachings, history, and practices. New York: Cambridge University Press.

Klassen, P. 2005. Ritual appropriations and appropriate ritual: Christian healing and adaptations of Asian religions. History and Anthropology 16:377-91.

Layman, E. 1976. Buddhism in America. Chicago: Nelson Hall.

Li, Y. 2000. Ordination, legitimacy, and sisterhood: The international full ordination ceremony in Bodhgaya. In Innovative Buddhist women: Swimming against the stream, edited by K. Tsomo, 168-98. Surrey: Curzon.

McGuire, M. and O. Maduro. 2005. Introduction. Social compass. 52:411-415.

Miller, V. 2003. Consuming religion: Christian faith and practice in a consumer culture. New York: Continuum Publishing Group.

Mitchell, D. and J. Wiseman. 1999. The Gethsemani encounter: A dialogue on the spiritual life by Buddhist and Christian monastics. New York: Continuum.

Orsi, R. 2003. Is the study of lived religion irrelevant to the world we live in? Journal for the Scientific Study of Religion 42:169-74.

Orsi, R. 1985. The Madonna of 115 Street: Faith and community in Italian Harlem, 1880-1950. New Haven: Yale University Press.

Perron, G. 2005. Monastic interreligious dialogue: A report to the General Chapter of the American-Cassinese Benedictine Congregation. Monastic Interreligious Dialogue Bulletin.

Prebish, C. 1979. American Buddhism. North Scituate, MA: Duxburg Press.

1999. Luminous passage: The practice and study of Buddhism in America. Berkeley: University of California Press.

Prebish, C. and K. Tanaka, eds. 1998. The faces of Buddhism in America. Berkeley: University of California Press.

Prothero, S. 1996. The white Buddhist: The Asian odyssey of Henry Steel Olcott. Bloomington: Indiana University Press.

Roof, W. C. 1993. A generation of seekers: The spiritual journeys of the baby boom generation. New York: Harper San Francisco.

Seager, R. 1999. Buddhism in America. New York: Columbia University Press .

Stewart, C. 1999. Syncretism and its synonyms: Reflections on cultural mixture. Diacritics 29:40-62.

Stirrat, R.L. 1992. Power and religiosity in a post-colonial setting: Sinhala Catholics in Contemporary Sri Lanka. Cambridge: Cambridge University Press.

Swearer, D. 1995. The Buddhist world of Southeast Asia. Albany: SUNY Press.

Thal, S. 2005. Rearranging the landscape of the gods: The politics of a pilgrimage site in Japan, 15731912. Chicago: University of Chicago Press.

Tsomo, K. 2002. Buddhist nuns: Changes and challenges. In Westward dharma: Buddhism beyond Asia, edited by C. Prebish and M. Baumann, 255-74. Berkeley: University of California.

Tweed, T. 1992. The American encounter with Buddhism. Bloomington: University of Indiana Press.

Tweed, T. 1999a. Night-Stand Buddhists and other creatures: Sympathizers, adherents, and the study of religion. In American Buddhism: Methods and findings in recent scholarship, edited by D.Williams and C. Queen, 71-90. Surrey: Curzon.

Tweed, T. 1999b. General introduction. In Asian religions in America: A documentary history, edited by T. Tweed and S. Prothero, 1-12. New York: Oxford University Press.

Warner, R. S. and J. Wittner, eds. 1998. Gatherings in diaspora: Religious communities and the new immigration. Philadelphia: Temple University Press. 
Williams, D. and C. Queen, eds. 1999. American Buddhism: Methods and findings in recent scholarship. Surrey: Curzon Press.

Wittberg, P. 1993. Residence stability and decline in Roman Catholic religious orders of women: A preliminary investigation. Journal for the Scientific Study of Religion 32:76-82. . 1994. The rise and fall of Catholic religious orders: A social movement perspective. Albany: State University of New York Press.

Wuthnow, R. 1998. After heaven: Spirituality in America since the 1950s. Berkeley: University of California Press.

Wuthnow, R and W. Cadge. 2004. Buddhists and Buddhism in the United States: The scope of influence. Journal for the Scientific Study of Religion 43:361-78. 